\title{
Eucalyptus Trees Plantation: A Review on Suitability and their Beneficial Role
}

\author{
Amanpreet Kaur ${ }^{*}$ and Rajesh Monga ${ }^{2}$
}

${ }^{1}$ Dept. of Silviculture and Agroforestry, ${ }^{2}$ Dept. of Tree Improvement and Genetic Resources, Dr. Yaswant Singh Parmar University of Horticulture and Forestry, Solan, Himachal Pardesh (173 230), India

Open Access

Corresponding Author

Amanpreet Kaur

e-mail: amanjambh59@gmail.com

Citation: Kaur and Monga, 2021. Eucalyptus Trees Plantation: A Review on Suitability and Their Beneficial Role. International Journal of Bio-resource and Stress Management 2021, 12(1), 016-025. HTTPS://DOI. ORG/10.23910/1.2020.2174.

Copyright: (c) 2020 Kaur and Monga. This is an open access article that permits unrestricted use, distribution and reproduction in any medium after the author(s) and source are credited.

Data Availability Statement: Legal restrictions are imposed on the public sharing of raw data. However, authors have full right to transfer or share the data in raw form upon request subject to either meeting the conditions of the original consents and the original research study. Further, access of data needs to meet whether the user complies with the ethical and legal obligations as data controllers to allow for secondary use of the data outside of the original study.

Conflict of interests: The authors have declared that no conflict of interest exists.

Acknowledgement: The authors are thankul to the Head of Department of Silviculture and Agroforestry, Dr. Yaswant Singh Parmar University of Horticulture and Forestry, Solan and to Department of Science and Technology for supporting financially as INSPIRE fellow and for their kind cooperation.

\begin{abstract}
Eucalyptus is fastest growing species popularly known as gum tree, red iron tree, safeda and belonging to the family Myrtaceae. E. tereticornis and E. grandis are important commercial species with a clean straight bole and compact crown. Large scale plantations have been raised on forest and farm lands, community lands, field boundaries and road/rail/canal strips in India. It is most suitable species for degraded land, waterlogged areas, problematic soils etc. Although, it is a controversial tree because of high water consumption, nutrient depletion, allopathic effects etc., it is also source of pulp, paper, essential oil, timber, medicinal use, etc. Moreover it also provides ecological, socioeconomic and industrial services. Improvement in physical and chemical properties of on Sodic wastelands, heavy metal accumulation in different tissues of in mined soil; carbon sequestration potential, etc. were reported in studies. On unit basis of dry biomass produced, it consumes very little water compared to other trees. If bark of the tree is left on site, the balance of nutrients remaining is $(80-88 \%)$ of inputs for $\mathrm{N}, \mathrm{P}, \mathrm{K}, \mathrm{Ca}$ and $\mathrm{Mg}$ which lasts for several years without considering the original nutrients that are still present in soil. In the face of growing economy and increased demand for wood products, it remains to be the desired species that grows fast and produce wood to meet the demand of wood for fuel, construction and furniture materials. Relieving wood product scarcity, landscape re-greening, contribution to poverty reduction, biodiversity restoration and conservation are valuable contribution in forest sector.
\end{abstract}

Keywords: Eucalyptus, sodics, waterlogged, socio-economic, allopathic, degraded land etc

\section{Introduction}

In the late $18^{\text {th }}$ century, Eucalyptus, a native of Australia where more than 600 Eucalyptus species are found and was brought into India. Eucalyptus is the species most widely introduced is a long and ever green tree belonging to family Myrtaceae (Rassaeifar et al., 2013). Eucalyptus, a genus of more than 500 species, has become the most planted genus of tree in the world (Teketay, 2000). The major Eucalyptus growing countries are: China (170 million ha); India (2.5 million ha); and Brazil (3.7 million ha) (Davidson, 1995; Stape et al., 2001; Liu and Li, 2010). Also it has performed so well in the country that it is now one of the most popular agro forestry species with the Punjab, Haryana and many other states farmers. The average annual productivity of natural forests in India is less than $2 \mathrm{~m}^{3} \mathrm{ha}^{-1}$, while Eucalyptus plantations have an average

Article History

RECEIVED in $20^{\text {th }}$ December 2020 RECEIVED in revised form 02 $2^{\text {nd }}$ February 2021 ACCEPTED in final form $15^{\text {th }}$ February 2021 
annual productivity of 6-10 $\mathrm{m}^{3} \mathrm{ha}^{-1}$ in forests and $15-20 \mathrm{~m}^{3} \mathrm{ha}^{-1}$ in farmlands. The 7-year old clonal trees have yielded 20 to $39 \mathrm{~m}^{3} \mathrm{ha}^{-1} \mathrm{yr}^{-1}$ of wood, based on trials conducted in Andhra Pradesh. It is popularly known as the gum tree, red iron tree, safeda and belongs to myrtaceae family. More than 700 species have been recorded; the majority of the species are Australian native. Global total Eucalyptus plantation area in India is $20.2 \%$. It was first introduced by Tippu Sultan in India in 1790, which obtained seed from Australia and introduced some 16 species E. tereticornis and E. grandis.

It is large commercial species with a clean straight bole and a compact crown. E. tereticornis species have been shown to be frost-tolerant and can withstand 1 to 15 frost incidences in cold season. Large-scale plantations of Eucalyptus were grown in India on forest and farmland, community lands, field borders and road/rail/canal strips. It is a source of paper and pulp, timber, wood fuel, charcoal, pesticide and medicinal products, main pollen source in apiculture, etc. E. camaldulensis is suitable species for Himachal Pradesh, Uttrakhand; E. globulus is for Kerala, Karnataka; E. grandis is for Kerala (high rainfall areas); E. tereticornis is for Punjab, Haryana, Uttar Pradesh, Rajasthan, Gujarat, Madhya Pradesh, Maharashtra, Bihar, Odisha, West Bengal, Andhra Pradesh, Karnataka, Himachal Pradesh and Tamil Nadu; and E. citriodora is for Hilly areas. It is also suitable for saline or sodic soils, waterlogged area for purposes of draining excess water, and area degraded due to soil erosion that results in loss of soil fertility. It is also useful as shelter belts and wind breaks on large scale farm, farm lands as plantations. It grows under a wide range of climatic/soil conditions from warm to hot, sub humid to humid and from good to degraded soils. Farmers' raised interest in eucalypt farm forestry has now caused for conversion of croplands into eucalypt woodlots (Dereje et al., 2012).

An engineered product where green $E$. grandis finger-jointed with green glue has far lower levels of splits, and has very different properties to existing softwood resources, making it more cost efficient for this wood resource to establish new stress grades (Wessels et al., 2020). In their leaves, more than 300 Eucalyptus species contain volatile essential oil. Around 20 species have a high 1,8-cineole content (more than 70\%), which is commercially used for the production of essential oils in the pharmaceutical and cosmetic industries (Dhakad et al., 2017). Eucalyptus camaldulensis essential oils showed a more complex composition with 54 compounds comprising $95 \%$ of the total reported leaf oil and 1,8-cineole (16.2\%) was the most abundant monoterpene, closely followed by alpha pinene (15.6\%) found in a research sample (Gakuubi, 2016). In 2015, El-Baz et al., concluded in a report that Eucalyptus was affected by Rotavirus strain, Coxsackie virus B4, and Herpes virus type-1. E. camaldulensis essential oil with a 50, 53.3 and 90 percent reduction rate, respectively (Adeniyi et al., 2015). Rani et al., 2016 reported that leaf oil fumigant toxicity of E. Globulus against the adult Musa domestica fiesta.
Essential leaf oil of $E$. Globulus had red mite repellent activity (Dermanyssus gallinae) (Samani et al., 2015). Oil in the Leaf of E. globules has Maximum antibacterial activity against $S$. aureus, while the minimum activity for $P$. aeruginosa, was demonstrated by (Bachheti, 2015). Essential leaf oil of $E$. lanceplatus as a concentration of $3 \mathrm{~g} \mathrm{~kg}^{-1}$, showed maximum fungicidal activity, showing $85.5 \%$ inhibition against Alternaria alternate (Bhagat et al., 2016). Essential oil of the leaf extracted from $E$. urophylla and $E$. Grandis has anti-fungal activity against Fusarium graminearum, Rhizoctonia solani, Magnaporthe grisea, Colletotrichum gloeosporioides, Alternuria longipes, Alternaria solani, Botrytis cinerea, Bipolaris maydis, Fusarium moniliforme, Rhizoctonia solani and Setosphaeria turcica was demonstrated with an inhibition rate of $25-91 \%$ and marked morphological and structural alterations of hypha (Zhou et al., 2016). Despite its widespread usefulness Eucalyptus has drawn adverse affects. Even a layman who is not concerned with it makes derogatory remarks such as "it sucks water and reduces water table" or "it spoils property." There are several controversies regarding eucalyptus planting, such as excessive use or consumption of water, allochemicals have a negative effect on agricultural production and are a more important factor in dry regions (Lisanework and Michelsen, 1993; Ahmed et al., 2008), eucalyptus trees deplete and compete for soil nutrients needed by agricultural crops (Michelsen et al., 1993; Jiregna, 2003), through shading (Chanie et al., 2013), enhance soil erosion and provide shelter or food for native wildlife (Chin, 2006), suppress undergrowth, cannot, poor fuel quality, etc.

Biased actions against eucalyptus by Poore and Fries (1987) suggest double standards used in evaluating forestry crops compared to agricultural crops. Most agricultural crops in any area are introduced species and continuous farming includes fertilizer addition, both of these basics are accepted. But Eucalyptus is viewed as an exotic when it comes to forestry, even in regions where it has been domiciled for over two centuries. It is continually cultivated in cycles of 4 to 6 years, and then blamed for nutrient and water consumption. Pearl millet and maize absorb over $150 \%$ of the wheat water. Rice uses the water used by pearl millet and maize more than twice it. They take their water needs for granted. However, in the case of Eucalyptus, even though it has been shown to be the most effective water user, generating biomass commensurate with the water consumed; it is labelled as an excessive consumer of water. The National Agriculture Commission (1976) estimated that by the turn of the century there would be about 17 million $\mathrm{m}^{3}$ of pulpwood requirement in the country and a deficit of 13 million $\mathrm{m}^{3}$ and there was a great need to improve the productivity of Indian forest. The planting of eucalyptus will reduce the strain on natural forests, bridge the gap between demand and supply of pulp and firewood, fulfill the growing need for timber, and preserve biodiversity in the World. The demand for wood products on the market, unavailability of wood on the farm, high biomass 
production rate, ease of cultivation and broader adaptability, non-palatability to livestock are the key factors driving farmers to plant Eucalyptus (Mekonnen et al., 2007). Some recent evidence from the literature indicates that Eucalyptus does not always have detrimental effects on the retention of topsoil and the supply of soil nutrients. Eucalyptus, for example, will serve as shelterbelts for crops if properly planted (Zegeye, 2010; Jagger and Pender, 2003). There are several major benefits of eucalyptus plantation which is to be discussed in the headlines; Ecological or Environment Benefits of Eucalyptus, socio- economic benefits and industrial benefits.

\section{Environment and Ecological Benefit}

Eucalyptus participates in the contribution of soil nutrients and stabilization of the topsoil by leaf litter on degraded hillsides and wastelands. It also improves physical and chemical properties of soil, reduces erosion and gully formation in previously barren slope, flooding and water extraction in areas with heavy rainfall. It requires lesser water consumption per $\mathrm{kg}$ of biomass produced and has rapid growth with good coppicing ability. Some species are resistant to droughts, floods and burning too. It is also efficient for capturing $\mathrm{CO}_{2}$, carbon fixation and oxygen production due to higher growth ability.

\subsection{Literature findings}

Mishra et al., 2003 conducted study on sodic wastelands in relation to age and depth; and found that with the age of $E$. tereticorniss plantation the organic carbon content (12.8 g $\mathrm{kg}^{-1}$ ) at $0-10 \mathrm{~cm}$ depth of $9 \mathrm{yr}$ plantation has been found to increase, and soil pH is decreased (8.02) at $0-10 \mathrm{~cm}$ depth of $9 y$ plantation due to the litter decomposition of root exudates and/or products. The great increase in the available $\mathrm{P}(28 \mathrm{mg}$ $\left.\mathrm{kg}^{-1}\right)$ and $\mathrm{K}\left(284 \mathrm{mg} \mathrm{kg}^{-1}\right)$ at $0-10 \mathrm{~cm}$ depth of $9 \mathrm{yr}$ plantation content was directly related to the quality of organic matter. The increase in the available $\mathrm{K}$ content may be due to the release of $\mathrm{K}$ from $\mathrm{K}$-bearing minerals after recovery and, in part, to the recycling of $K$ due to the decomposition of litter (Table 1).

Table 1: Improvement in chemical properties of soil supporting Eucalyptus tereticornis plantations on sodic wastelands in Sultanpur district, India

\begin{tabular}{|c|c|c|c|c|c|c|c|c|c|c|c|c|c|c|c|c|}
\hline \multirow[t]{2}{*}{ Depth (cm) } & \multicolumn{4}{|c|}{$\mathrm{pH}$} & \multicolumn{4}{|c|}{ Organic carbon $\left(\mathrm{g} \mathrm{kg}^{-1}\right)$} & \multicolumn{4}{|c|}{ Avail. $\mathrm{P}\left(\mathrm{mg} \mathrm{kg}^{-1}\right)$} & \multicolumn{4}{|c|}{ Avail. $\mathrm{K}\left(\mathrm{mg} \mathrm{kg}^{-1}\right)$} \\
\hline & C & $3 \mathrm{Yr}$ & $6 \mathrm{Yr}$ & $9 \mathrm{Yr}$ & C & $3 \mathrm{Yr}$ & $6 \mathrm{Yr}$ & $9 \mathrm{Yr}$ & C & $3 \mathrm{Yr}$ & $6 \mathrm{Yr}$ & $9 \mathrm{Yr}$ & C & $3 \mathrm{Yr}$ & $6 \mathrm{Yr}$ & $9 \mathrm{Yr}$ \\
\hline $0-10$ & 10.1 & 9.82 & 9.11 & 8.02 & 2.0 & 3.2 & 5.5 & 12.8 & 9.00 & 17.1 & 23.6 & 28.0 & 115 & 160 & 195 & 284 \\
\hline $10-30$ & 10.4 & 10.17 & 9.74 & 8.29 & 1.6 & 2.2 & 3.3 & 6.6 & 9.75 & 15.3 & 20.5 & 24.5 & 109 & 142 & 182 & 241 \\
\hline $30-60$ & 10.5 & 10.5 & 10.3 & 8.43 & 0.9 & 1.2 & 1.4 & 2.3 & 10.62 & 12.1 & 13.8 & 25.7 & 104 & 123 & 126 & 214 \\
\hline
\end{tabular}

Tree roots and grass foliage are responsible for the penetration of water into the substratum and thus increase the percolation of water within the soil that is by the infiltration rate $(2.4$ initial, 0.133 finial) at the plantation sites was high relative to the control sites (1.8 initial, 0.033 finial) (Table 2). After afforestation, the micropores increased in the soil due to the root network. The water carrying capacity of the soil has been seen to increase (52.9) with age of E. tereticornis plantation with the reduction of the bulk density $\left(1.01 \mathrm{~g} \mathrm{~cm}^{-2}\right)$, which could also be clarified in terms of organic matter, humus and tree formation.

Khan, 2003 conducted study on sodic soils of Uttar Pradesh and found that highest survival percentage is under Acacia nilotica (100\%) followed by Albizzia procera (98.6\%) and Terminalia arjuna (53.8\%). But highest plant height (1028 $\mathrm{cm}$ ) is obtained by eucalyptus due to their fastest growth and short rotation (Table 3).

Table 2: Improvement in physical properties of soil supporting Eucalyptus tereticornis plantations on sodic wastelands in Sultanpur district, India

\begin{tabular}{|c|c|c|c|c|c|c|c|c|c|c|c|c|}
\hline \multirow[t]{2}{*}{ Depth (cm) } & \multicolumn{4}{|c|}{ Porosity (\%) } & \multicolumn{4}{|c|}{ WHC } & \multicolumn{4}{|c|}{$\mathrm{BD}\left(\mathrm{g} \mathrm{cm}^{-2}\right)$} \\
\hline & C & $3 y r$ & $6 \mathrm{yr}$ & $9 \mathrm{yr}$ & C & $3 \mathrm{yr}$ & $6 \mathrm{yr}$ & $9 \mathrm{yr}$ & C & $3 \mathrm{yr}$ & $6 \mathrm{yr}$ & $9 \mathrm{yr}$ \\
\hline $0-10$ & 41.2 & 44.9 & 47.5 & 50.9 & 43.3 & 45.7 & 48.2 & 52.9 & 1.66 & 1.39 & 1.27 & 1.01 \\
\hline $10-30$ & 41.4 & 45.2 & 47.6 & 52.8 & 44.8 & 46.6 & 47.9 & 52.2 & 1.59 & 1.39 & 1.27 & 1.01 \\
\hline $30-60$ & 42.2 & 44.2 & 45.0 & 47.5 & 44.6 & 45.6 & 47.6 & 49.1 & 1.66 & 1.48 & 1.38 & 1.01 \\
\hline $60-90$ & 35.4 & 37.7 & 38.4 & 44.2 & 44.3 & 45.1 & 47.0 & 48.1 & 1.72 & 1.56 & 1.45 & 1.07 \\
\hline \multicolumn{13}{|c|}{ Infiltration rate $\left(\mathrm{cm} \mathrm{ha}^{-1}\right)$} \\
\hline & & C & $3 y r$ & $6 y r$ & $9 \mathrm{yr}$ & & & & & & & \\
\hline \multicolumn{2}{|c|}{ Initial after 5 mint } & 1.8 & 2.4 & 2.4 & 2.4 & & & & & & & \\
\hline \multicolumn{2}{|c|}{ Finial after 455 mint } & 0.033 & 0.066 & 0.100 & 0.133 & & & & & & & \\
\hline
\end{tabular}


Table 3: Rehabilitation of sodic soil through different trees species

\begin{tabular}{lcc}
\hline Tress & $\begin{array}{c}\text { Survival } \\
\text { percentage \% }\end{array}$ & $\begin{array}{c}\text { Plant } \\
\text { height }(\mathrm{cm})\end{array}$ \\
\hline Azadirachta indica & 86.1 & 700 \\
Dalbergia sissoo & 87.5 & 638 \\
Albizzia procera & 98.6 & 745 \\
Terminalia arjuna & 90 & 635 \\
Eucalyptus hyrid & 59 & 1028 \\
Leucaena leucocephala & 85.4 & 855 \\
Acacia catechu & 58.3 & 650 \\
Acacia nilotica & 100 & 825 \\
Morus alba & 29.29 & 364 \\
Cacia siamea & 83.01 & 656 \\
\hline
\end{tabular}

Maiti and Rana, 2016 conducted study on mined soil in Jharkhand Known As the "Coal Capital of India. They found that higher concentrations of $\mathrm{Pb}$ in barks ( 3 times), $\mathrm{Zn}$ in leaves (4.5 times), $\mathrm{Mn}$ in leaves (19 times), and $\mathrm{Cu}$ in roots (1.4 times) were found in reclaimed mined soil in comparison with eucalyptus hybrid growing on Clean soil. In RMS Pb concentration is highest in root bark (38.5), $\mathrm{Zn}$ in leaf (176.4), $\mathrm{Mn}$ in leaf (1873.5), $\mathrm{Cu}$ in root wood (42.1) and $\mathrm{Co}$ in root wood (7.2) (Table 4) which is several time higher than clean soil. The emission of heavy metals can affect environment by contamination of the food chain by intruding heavy metals into cultivating land, the water runs through the polluted area may get polluted by heavy drainage, etc. Planting Eucalyptus hybrid trees for mine soil remediation has been found to be beneficial by improving metal contamination and acting as sinks to heavy metal pollution which reduces the metal load on natural drainage streams (Table 4).

Davidson, 1989, performed an analysis on eucalyptus and observed that if bark is left on site, the residual nutrient balance is $83,87,63,83$ and $82 \%$ of $\mathrm{N}, \mathrm{P}, \mathrm{K}, \mathrm{Ca}$ and $\mathrm{Mg}$ inputs, respectively. This reserve is adequate to last $34,42,14,35$, and 28 years respectively, without taking into consideration the already usable initial nutrients in the soil (Table 5). A

\begin{tabular}{|c|c|c|c|c|c|c|c|c|c|c|}
\hline \multirow{2}{*}{ Metals $\left(\mathrm{mg} \mathrm{kg}^{-1}\right)$} & \multicolumn{2}{|c|}{ Leaf } & \multicolumn{2}{|c|}{ Stem bark } & \multicolumn{2}{|c|}{ Stem wood } & \multicolumn{2}{|c|}{ Root bark } & \multicolumn{2}{|c|}{ Root wood } \\
\hline & RMS & CS & RMS & CS & RMS & CS & RMS & CS & RMS & CS \\
\hline $\mathrm{Pb}$ & 16.2 & 4.4 & 41.2 & 6.2 & 29.7 & 1.4 & 38.5 & 17.2 & 32.2 & 7.1 \\
\hline $\mathrm{Zn}$ & 176.4 & 46.2 & 52.3 & 8.7 & 60.3 & 38.1 & 74.2 & 16.7 & 72.7 & 27.7 \\
\hline $\mathrm{Mn}$ & 1873.5 & 103.1 & 641.1 & 8.5 & 383.75 & 9.3 & 132.1 & 6.6 & 91.1 & 8.6 \\
\hline $\mathrm{Cu}$ & 15.75 & 8.5 & 16.6 & 4.1 & 23.8 & 9.1 & 22.1 & 10.1 & 42.1 & 26.2 \\
\hline Co & 4.45 & bdl & 10.6 & bdl & 6.5 & bdl & 5.5 & Bdl & 7.2 & Bdl \\
\hline
\end{tabular}

Bdl: below detectable limit, RMS: reclaimed mined soil, CS: Clean sites

large proportion of the nutrients in a tree crop is retained in the foliage and is recycled to the soil annually. This nutrient turnover is responsible for soil productivity enhancement by plantations built at previously cleared sites. When trees grow older than approximately seven years, the amount of nutrients available per unit volume of wood steadily decreases. So, harvesting more mature trees leads to even less drain of nutrient on the site.

Increased organic matter content from decomposition of the leaf litter may have resulted in improvement in: capacity to retain soil water, porosity, hardness, vital nutrients, crop yield improvement. Types of quickly growing tree adapted to especially harsh sites have an significant role in land regeneration and restoration. Tree cover has significance in soil preservation and enhancement of beneficial physical and chemical properties. The change of the soil quality is attributed to the presence of a litter layer beneath all tree species.

Ram et al. (2011) conducted study in water logged fields of Puthi village in Haryana where $10 \%$ of the land $10.44 \mathrm{~m}$ ha) is waterlogged resulting in reduced crop yield. Increase in groundwater table accompanied by water logging and secondary salinization of soil is a serious problem in arid and semi-arid canal-irrigated areas. In 2002 four parallel Clonal (E. tereticornis) stripe-plants were reared. In the period 2005 to 2008, groundwater table levels were averaged over 3 years. In nearby areas, the groundwater level beneath the strip-plants remained smaller than that. The wheat yield in the strip-plant interspaced was 3.4 times that in neighboring water-logged areas without plantation (Figure 1 and Table 6). These plantations produced $46.6 \mathrm{t} \mathrm{ha}^{-1}$ fresh biomass with 3.5 benefit-cost ratio, and $15.5 \mathrm{t}_{\text {carbon }} \mathrm{ha}^{-1}$ sequestered (Table 6). Many researchers have proposed that salt-affected, waterlogged lands be rehabilitated through tree plantations. Eucalyptus not only reduces the water table but also gets high prices and produces fuel oil. A valuable method for carbon sequestration is the reclaiming of waterlogged, salt-affected lands that are low in organic carbon by fast growing plantations. Rising soil carbon by plantations can 
Table 5: Soil nutrient balance and nutrients in the litter of eucalyptus plantation

\begin{tabular}{|c|c|c|c|c|c|c|c|}
\hline \multirow{2}{*}{$\begin{array}{l}\text { Age } \\
\text { (Yrs) }\end{array}$} & \multirow{2}{*}{$\begin{array}{l}\text { Litter } \\
\left(\text { t ha }^{-1}\right)\end{array}$} & \multicolumn{6}{|c|}{ Nutrient $\left(\mathrm{kg} \mathrm{ha}^{-1}\right)$ in the litter of Eucalyptus plantation } \\
\hline & & $\mathrm{N}$ & $P$ & K & $\mathrm{Ca}$ & $\mathrm{Mg}$ & S \\
\hline 1 & 1.2 & 13 & 0.9 & 4.9 & 19.3 & 3.1 & 2.7 \\
\hline 2 & 4.0 & 39 & 3.4 & 11.9 & 54.7 & 8.8 & 7.5 \\
\hline 3 & 5.5 & 48.8 & 3.2 & 16.1 & 65.5 & 10.3 & 10.6 \\
\hline 4 & 8.3 & 54.4 & 2 & 27.5 & 61.3 & 12.2 & 18.5 \\
\hline 5 & 11 & 59.1 & 2.3 & 27.3 & 77.1 & 12.9 & 14.9 \\
\hline 6 & 10 & 85.9 & 7.2 & 32.8 & 88.8 & 14.2 & 15.5 \\
\hline 7 & 7.4 & 55.8 & 4.6 & 19.3 & 74.3 & 14.6 & 10.9 \\
\hline Total & 47.5 & 355 & 23.7 & 139.9 & 441.1 & 76.2 & 80.7 \\
\hline \multicolumn{8}{|c|}{ Soil nutrients $\left(\mathrm{kg} \mathrm{ha}^{-1}\right)$ balance after a seven year rotation } \\
\hline Input & & 455 & 60 & 237 & 607 & 96 & \\
\hline Accur & ound bio-mass & 179 & 15 & 164 & 381 & 56 & \\
\hline Outp & & 77 & 8 & 87 & 104 & 17 & \\
\hline Left o & ches, bark & 102 & 7 & 77 & 277 & 39 & \\
\hline Balan & after harvest & 378 (83\%) & 52 (87\%) & 148 (63\%) & 504 (83\%) & 79 (82\%) & \\
\hline
\end{tabular}

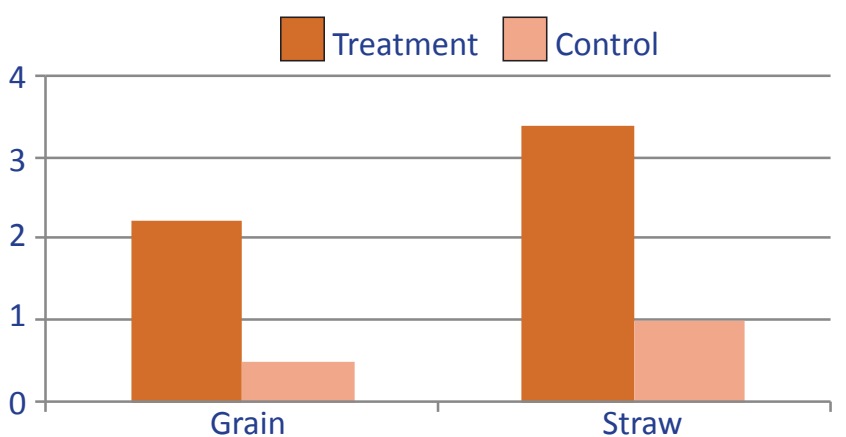

Figure 1: Wheat yield obtained with and without Eucalyptus plantation in Haryana

also serve as a major sink in carbon. Aside from reducing the groundwater table, Eucalyptus plantation offers significant carbon sequestration benefits. Eucalyptus grows quickly

Table 6: Fresh and dry biomass, carbon sequester t ha-1 under strip plantation in Haryana

\begin{tabular}{lccccc}
\hline Tree component & \multicolumn{2}{c}{$\begin{array}{c}\text { Fresh } \\
\text { biomass }\end{array}$} & \multicolumn{2}{c}{$\begin{array}{c}\text { Dry } \\
\text { biomass }\end{array}$} & $\begin{array}{c}\text { Carbon } \\
\text { sequester } \\
\end{array}$ \\
\cline { 2 - 5 } & $\begin{array}{c}\mathrm{kg} \\
\mathrm{tree}^{-1}\end{array}$ & $\begin{array}{c}\mathrm{t} \\
\mathrm{ha}^{-1}\end{array}$ & $\begin{array}{c}\mathrm{kg}^{-1} \\
\mathrm{tree}^{-1}\end{array}$ & $\begin{array}{c}\mathrm{t} \\
\mathrm{ha}^{-1}\end{array}$ & \\
\hline Timber & 131.6 & 31.6 & 92.1 & 22.1 & 10.4 \\
Fuel wood & 4.6 & 1.1 & 3.3 & 0.8 & 0.3 \\
Twigs and leaves & 6.4 & 1.5 & 4.5 & 1.1 & 0.5 \\
Total shoot & 142.7 & 34.2 & 99.9 & 24 & - \\
biomass & & & & & \\
Root & 51.4 & 12.3 & 37 & 8.9 & 4.3 \\
Total & 194.1 & 46.5 & 136.9 & 32.9 & 15.5 \\
\hline
\end{tabular}

and has high water-consumption potential when adequate water is available. The highest observed microbial population was also along the Eucalyptus plantation tree line. The main collapse of the leaf and litter occurred on elevated ridges, high above the surface. In comparison, allelopathic chemicals emitted may have been neutralized a few centimeters below the surface of the soil if any. Therefore the adverse effects of Eucalyptus release of toxins on crops and soil microbes were not anticipated. Owing to improved production and viability, eucalyptus clones have been widely introduced to make the farm forestry an appealing choice for land use.

National green tribunal (NGT) in its order dated 20 july 2015 in original application No. 9 of 2014, in para 31 clearly stated that based on studies conducted in different countries, growing of eucalyptus, one of the major farm forestry species, has no adverse effect nor is it disastrous for water table, as it consumes less water per kg of biomass generated versus many trees and agricultural crops (Table 7).

Chaturvedi et al., 1988 also recorded that water consumption per generated biomass is the lowest in eucalyptus planting compared to other crops and trees. They found that Eucalyptus hybrid consumes 5324 liters year ${ }^{-1}$ water and produced 10418 $\mathrm{g}$ of biomass, which is higher than comparative species (Table 8).

Ghosh et al., 2014 reported decrease in soil pH (8.65) in eucalyptus based system compared to sole crops (8.81) after 5 year of plantation compared to initial year in Karnal, India. Whereas, decrease EC $\left(0.45 \mathrm{dS} \mathrm{m}^{-1}\right)$ eucalyptus based system to $\left(0.32 \mathrm{dS} \mathrm{m}^{-1}\right)$ in sole crop and organic carbon \% $(0.37 \%)$, Nitrogen $\left(86 \mathrm{~kg} \mathrm{ha}^{-1}\right)$, Phosphorus (18.5 kg ha $\left.{ }^{-1}\right)$, Potassium ( $259 \mathrm{~kg} \mathrm{ha}^{-1}$ ) in eucalyptus based system increased 


\begin{tabular}{llc}
\hline \multicolumn{3}{l}{ Table 7: Water consumption of different trees and crops per } \\
total biomass produced by IPMA \\
\hline Sr. & Plant & $\begin{array}{c}\text { Water use per total } \\
\text { biomass }\left(\mathrm{kg}^{-1}\right)\end{array}$ \\
No. & & 3200 \\
\hline 1 & Cotton/Coffee/Banana & 2600 \\
2 & Pongomia (T) & 2400 \\
3 & Sunflower & 2000 \\
4 & Field pea & 2000 \\
5 & Paddy rice & 1714 \\
6 & Horse bean & 1667 \\
7 & Cow pea & 1538 \\
8 & Conifers (T) & 1483 \\
9 & Dalbergia (T) & 1430 \\
10 & Soyabean & 1323 \\
11 & Acacia & 1017 \\
12 & Syzygium & 1000 \\
13 & Pototo & 1000 \\
14 & Sorghum & 967 \\
15 & Albizia (T) & 785 \\
16 & Eucalyptus (T) & 592 \\
\hline & Finger millet & \\
\hline
\end{tabular}

Table 8: water consumption per biomass production of eucalypts compared with other tree species

\begin{tabular}{lccc}
\hline Tree species & $\begin{array}{c}\text { Water } \\
\text { consumed } \\
(\text { liters } \\
\left.\mathrm{yr}^{-1}\right)\end{array}$ & $\begin{array}{c}\text { Biomass } \\
\text { produced } \\
(\mathrm{g})\end{array}$ & $\begin{array}{c}\text { Water con- } \\
\text { sumption/ } \\
\text { Biomass pro- } \\
\text { duction }\left(\mathrm{g} \mathrm{g}^{-1}\right)\end{array}$ \\
\hline $\begin{array}{l}\text { Acacia } \\
\text { auriculiformis }\end{array}$ & 2950 & 3426 & 0.86 \\
Albizzia lebbek & 2742 & 4710 & 0.58 \\
Dalbergia sissoo & 3588 & 4010 & 0.89 \\
Eucalyptus hybrid & 5324 & 10418 & 0.51 \\
Pongamia pinnata & 1358 & 1040 & 1.30 \\
Azadirachta indica & 1481 & 1646 & 0.90 \\
Acacia nilotica & 2971 & 3904 & 0.76 \\
Prosopis juliflora & 3468 & 4883 & 0.71 \\
Syzigium cumini & 2920 & 4772 & 0.61 \\
\hline
\end{tabular}

in comparison in sole crop (Table 9).

\section{Socioeconomic Benefits olf Eucalyptus}

Rising eucalyptus is considered a Farmers' Green Bank account (income / food security). Eucalyptus is a high value cash crop that provides jobs. Owning the stand of Eucalyptus is a sign of wealth and affluence. It also approved bank borrowing capital
Table 9: Soil properties affected by land-use systems at Karnal, India

\begin{tabular}{|c|c|c|c|c|c|c|}
\hline \multirow{2}{*}{$\begin{array}{l}\begin{array}{l}\text { Land-use } \\
\text { system }\end{array} \\
\text { Initial soil } \\
\text { properties }\end{array}$} & \multicolumn{6}{|c|}{ Available nutrients, $\mathrm{pH}, \mathrm{EC}$ and $\mathrm{OC}$} \\
\hline & $\mathrm{pH}$ & $\begin{array}{c}\mathrm{EC}\left(\mathrm{dS}^{-}\right. \\
\left.{ }^{1} \mathrm{~m}\right)\end{array}$ & $\begin{array}{l}\text { OC } \\
(\%)\end{array}$ & $\begin{array}{l}\mathrm{N}(\mathrm{kg} \\
\left.\mathrm{ha}^{-1}\right)\end{array}$ & $\begin{array}{l}\mathrm{P}(\mathrm{kg} \\
\left.\mathrm{ha} \mathrm{A}^{-1}\right)\end{array}$ & $\begin{array}{l}\mathrm{K}(\mathrm{kg} \\
\left.\mathrm{ha}^{-1}\right)\end{array}$ \\
\hline Sole crops & 9.26 & 0.56 & 0.22 & 65 & 14.3 & 238 \\
\hline $\begin{array}{l}\text { Eucalyptus- } \\
\text { based system }\end{array}$ & 9.32 & 0.61 & 0.25 & 65 & 13.8 & 224 \\
\hline \multicolumn{7}{|l|}{ After 5 years } \\
\hline Sole crops & 8.81 & 0.45 & 0.29 & 75 & 13.6 & 208 \\
\hline $\begin{array}{l}\text { Eucalyptus- } \\
\text { based system }\end{array}$ & 8.65 & 0.32 & 0.37 & 86 & 18.5 & 259 \\
\hline
\end{tabular}

(Access to Credit) as collateral in some countries. Farmers cultivate eucalyptus to ensure continuity of land ownership in the case of a dispute, even whether the landowner cannot farm the land for any purpose. They manufacture poles and fuel-wood within a short time. For many rural farmers it served as a buffer against financial crisis on land unsuitable for productive farming. It is also useful for certain medicinal remedies like mouth gargles, tooth-pastes, mosquito repellents, etc.

\subsection{Literature findings}

Agarwal et al., 2017 analyses various crops (Rice, Cotton and Wheat) and trees (Subabul, Eucalyptys, Casuarina) in Gujarat and Maharashtra and compared their overall investment, overall sales, market price, net profits, etc. They reported that all these parameters in Eucalyptus were higher than other species being analyzed. The net production from the plantation of eucalyptus is 43860 per acre per year with total expenditure of ₹ 25,400 , which is the largest of all other species such as Subabul (34833), Casuarina (28833), Cotton (33860), Rice (24360), Wheat (19000) with total expenditure of $12500,14500,28140,10640,8500$, respectively (Table 10).

Luna, 1996 stated that the planting of eucalyptus on bunds without losing the agricultural crops is economically feasible for small farmers. The conclusions drawn were that eucalypts planting in combination with agricultural crops at $6.0 \times 1.0 \mathrm{~m}^{2}$ spacing with eight year rotation gave the highest net present value and benefit cost ratio at $12 \%$ rate of interest in Haryana, Punjab and Uttar Pradesh. The IRR (internal rate of return) was found to be more for $4.0 \times 2.0 \mathrm{~m}^{2}$ spacing with intercropping in these states. The study concluded that for small farmers planting of eucalypts on bunds is economically viable without sacrificing the agricultural crops. It was recommended that cultivation of eucalypts at wider spacing in combination with agricultural crops at eight years rotation ensures high economic returns (Table 11). Eucalypt plantations on agricultural farms proved to be highly economical giving an internal rate of return of $35 \%$ to $38 \%$ without intercropping 


\begin{tabular}{lcccccc}
\hline \multicolumn{7}{l}{ Table 10: Comparison of eucalyptus plantation with different trees and crops } \\
\hline Particulars & $\begin{array}{c}\text { Subabul } \\
\text { (Rotation 3 yr) }\end{array}$ & $\begin{array}{c}\text { Eucalyptus } \\
\text { (Rotation 3 yr) }\end{array}$ & $\begin{array}{c}\text { Casuarina } \\
\text { (Rotation 3 yr) }\end{array}$ & $\begin{array}{c}\text { Cotton } \\
\text { (1 year) }\end{array}$ & $\begin{array}{c}\text { Rice } \\
\text { (7 months) }\end{array}$ & $\begin{array}{c}\text { Wheat } \\
\text { (7 months) }\end{array}$ \\
\hline Total expenditure (₹) & 12500 & 25400 & 14500 & 28140 & 10640 & 8500 \\
Total yield (acre) & $35 \mathrm{MT}$ & $40 \mathrm{MT}$ & $30 \mathrm{MT}$ & $1500 \mathrm{~kg}$ & $2000 \mathrm{~kg}$ & $1500 \mathrm{~kg}$ \\
Sale price MT-1 (₹) & 3200 & 3800 & 3200 & 40 & 15 & 15 \\
Total Revenue (sale pricexyield) & 112000 & 152000 & 96000 & 60000 & 30000 & 22500 \\
Firewood/rice or wheat straw & 5000 & 5000 & 5000 & 2000 & 5000 & 5000 \\
Total revenue+fire-wood/straw & 117000 & 157000 & 101000 & 62000 & 35000 & 27500 \\
Net income (₹) & 104500 & 131600 & 86500 & 33860 & 24360 & 19000 \\
Net income acre ( $^{-1}$ year & 34833 & 43860 & 28833 & 33860 & 24360 & 19000 \\
\hline
\end{tabular}

Table 11: Economics of Eucalypts with and without intercropping of 8 year plantation

\begin{tabular}{lccc}
\hline Spacing $(\mathrm{m})$ & $\begin{array}{c}\text { No of } \\
\text { plants ha }\end{array}$ & $\begin{array}{c}\text { NPV } \\
(@ 12 \%)\end{array}$ & $\begin{array}{c}\text { IRR } \\
(\%)\end{array}$ \\
\cline { 1 - 3 } Without cropping & & & \\
\cline { 1 - 2 } $2.5 \times 2.5$ & 1600 & 21422 & 40 \\
$3 \times 1.5$ & 2222 & 14687 & 32 \\
With inter cropping & & & \\
\hline Bund planting 2 m apart & 200 & 31681 & \\
$2.5 \times 2.5$ & 1600 & 15563 & 64.6 \\
$3 \times 1.5$ & 2222 & 8727 & 40 \\
$4 \times 2$ & 1250 & 11914 & 73 \\
$6 \times 1$ & 1666 & 17022 & 63 \\
\hline
\end{tabular}

and $85 \%$ with intercropping (Dogra, 1984). Good quality land should not be brought under eucalypts unless inter cropping is practiced. A research from the Center for Science and Environment (CSE) (The Mystery of Forest Productivity, 2017) says that plantation of eucalyptus produces more annual net income to farmers than approximately $60-70 \%$ of farm crops. The National Green Tribunal (NGT) reported that, based on studies in different countries, eucalyptus, one of the main farm forestry species, has no adverse environmental effects, nor is it catastrophic for the water table, because it consumes less water per kg of total biomass produced than many tree and agricultural crops. In a country like Ethiopia where the population has no other energy options and where around 90 per cent of the annually generated wood is used for cooking, it is therefore absolutely inappropriate to disfavor eucalyptus planting. Many farmers in Punjab have achieved high growth rates of 50-58 $\mathrm{m}^{3} \mathrm{ha}^{-1} \mathrm{yr}^{-1}$ which makes farm forestry an economically attractive land use choice with better returns compared to conventional crops (Piare, 2006).

\section{Industrial Benefits of Eucalyptus}

Eucalyptus stands out for its various, productive and renewable industrial applications. It is most suitable tree for pulp and green energy production. Eucalyptus means consistency in the printing, writing and tissue paper produce at a lower cost. Development of small size straight timber without knots, etc.

\subsection{Literature findings}

Rana et al., 2014 showing the production of eucalyptus pulp and paper worldwide. Global paper demand is $400 \mathrm{mt} \mathrm{yr}^{-1}$ and its usage was projected to rise to $500 \mathrm{Mt}$ by 2020 (Anonymous, 2010), whereas paper and paperboard use in India is expected to double from $10 \mathrm{mt} \mathrm{yr}^{-1}$ by 2020 (Mishra, 2011). While softwoods and hardwoods have attractive fibre characteristics for pulp and paper making, over-exploitation of these woods for various purposes has resulted in their production from natural forests continuing to decline (Ashori, 2006; Sharma et al., 2013). When India's paper industry faced an extreme scarcity of quality raw material, the division took an initiative to investigate the possibility of paper production from alternative sources such as eucalyptus, poplar and subabul, etc. Over the past decades, the division has carried out comprehensive research work on the suitability of different species for the development of pulp and paper, and a number of Indian paper mills have also developed technologies which were adopted. Eucalypt plantations are being established to supply raw material to the factories in the least possible period to fill the gap in demand and supply of timber. A specific quick growing plantation of diverse genus is being established in countries with good environmental conditions: Populus, Salix, Pinus and Eucalyptus. While there are over 600 species and varieties in the genus Eucalyptus, most grown on a commercial basis do not exceed the handful. One may list amongst them E. grandi, E. camaldulensis, E. balmulus, E. nitens, E. salline, E. tereticornis, E. viminalis, E. urophylla., E. globulus etc. In fast growing crops, E grandis predominate (Acosta et al., 2008). In India the paper and pulp industry was getting raw material from the forest departments or companies created plantation. National Forest Policy 1988, however, saw the pulp and paper industries increase their own planting to satisfy the demands. Clonal technology has been used especially for $E$. tereticornis for improved productivity. 
In India, by using marginal farm lands and their own captive plantations, much of the pulp wood requirement is currently met by farm forestry initiated by paper mills (Mishra, 2011). Eucalypts grow rapidly and offer excellent properties to a high pulp yield which makes it suitable for a wide range of papers. Analysis shows that, relative to other raw materials used in the paper industry, eucalyptus pulp has stronger intrinsic pulp properties (tensile/density relationship etc.). The eucalyptus pulp demonstrated a very strong potential for applications in value-added paper and paperboards, based on study of pulp properties. Indian paper industry faces a shortage of quality fibrous raw material, and eucalyptus remains one of the major fast-growing options for woody biomass, despite the competition from other wood-based industries in its availability for paper making (Figure 2 and 3).

$\%$ paper production $\square$ 3-D column $2 \square$ 3-D column 3

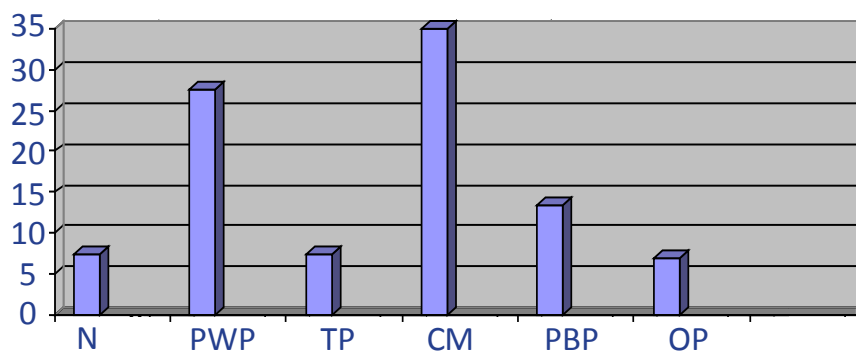

$\mathrm{N}$ : Newsprint; PWP: Printing and writing paper; TP: Tissue paper; CM: Corrugated material; PBP: Paper board for packaging; OP: Other paper

Figure 2: Global paper production of different grades from eucalyptus (SFIF, 2011)

$\%$ paper production $\square$ 3-D column $2 \square$ 3-D column 3

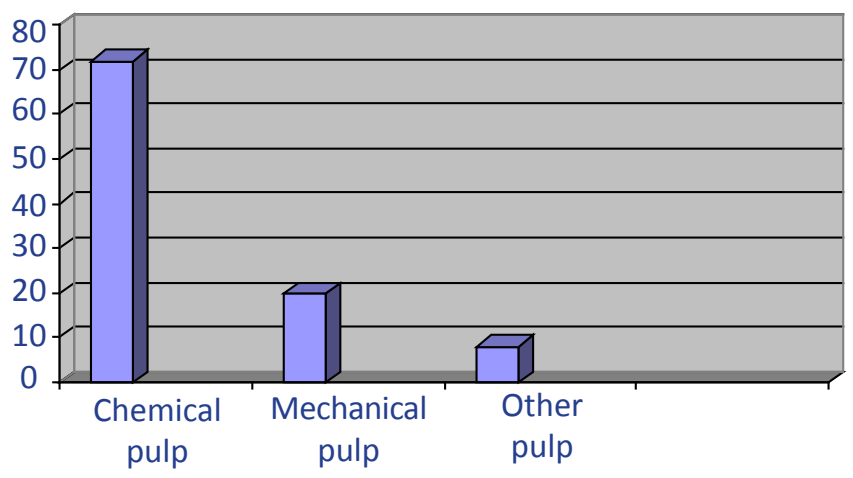

Figure 3: Global pulp production from Eucalyptus (SFIF, 2011)

\subsection{Concept of luxary consumpution}

The Eucalyptus culture controversy, along with unwarranted attention, has made this plant an object of hatred. Eucalyptus theory of "luxury consumption" is important to understand. Eucalyptus water transpiration is a function of the ambient humidity, the supply of surface water and the demand for leaf water. Under luxury water supply conditions, transpiration was found to be primarily a function of atmospheric $\mathrm{RH}$, rather than being regulated by stomatal mechanisms. The stomatal processes are tested by the supply of ground water. The turgor pressure is reduced under groundwater tension, resulting in the closing of stomata, which greatly decreases transpiration. This means eucalyptus requires more of it because the supply of soil water is not limited. Eucalyptus transpiration depends on the availability of moisture from the soil. Eucalyptus has the intrinsic capacity to drink water luxuriously while there is sufficient moisture available. Scientific forestry management in India is over 100 years old but Eucalyptus is the first tree that farmers have adopted for farmland cultivation due to its compatible with agricultural crops, quicker growth, shorter harvesting time and easier marketing. If there were any major detrimental impact on the supply of water or soil conditions from this crop, the farmers would not have proceeded to raise eucalyptus so vigorously. It indicates clearly that this criticism against eucalyptus is often mouthed by people who have no or relevant information about it and have little to do with agriculture and tree farming. Environmentalists, researchers and policy makers should put special focus on assisting land owners and farmers in choosing the right put to plant such as degraded land; steep slopes; waterlogging area; roadside etc.

\section{Conclusion}

Eucalypts were and will continue to receive attention at all times. As a significant crop of fast-growing, short-rotation, renewable biomass for high-quality paper production. Based on the unit weight provided by the dry biomass, eucalyptus absorbs very little water compared with other plants. It is also most suitable species for reclamation of waterlogged area, for saline and sodic soils, for mine soil and their plantation provides beneficial nutrient to soil which remains for several year. Relieving shortages of wood products, re-greening of habitats, leading to poverty reduction and hedge against financial crisis, preserving and conserving biodiversity are important contributions of eucalyptus in forest field.

\section{Acknowledgement}

The authors are thankul to the Head of Department of Silviculture and Agroforestry, Dr. Yaswant Singh Parmar University of Horticulture and Forestry, Solan and to Department of Science and Technology for supporting financially as INSPIRE fellow and for their kind cooperation.

\section{References}

Acosta, M.A., Mastrandrea, C., Lima, J.T., 2008. Wood technologies and uses of Eucalyptus wood from fast grown plantations for solid products. In: $51^{\text {st }}$ International Convention of Society of Wood Science and Technology, Concepcion, 10-12 November 2008. Papers WS-45.

Adeniyi, B.A., Ayepola, O.O., Adu, F.D., 2015. The antiviral activity of leaves of Eucalyptus camaldulensis (Dehn) and Eucalyptus torelliana (R. Muell). Pakistan Journal of Pharmaceutical Sciences 28(5), 1773-1776. 
Agarwal, N.K., Shukla, O.P. , Narkhede, S.L., Chauhan, S.K.S., 2017. Promotion of short rotation agro and farm forestry system in Gujarat and Maharashtra by JK paper limited unit-CPM. Indian Forester 143(9), 737-744.

Ahmed, R., Hoque, R., Hossain, M.K., 2008. Allelopathic effects of leaf litters of Eucalyptus camaldulensis on some forest and agricultural crops. Journal of Forestry Research, 19, 19-24.

Anonymous, 1976. Report of the National Commission on Agriculture, 1976: Forestry. Available From:https:// books.google.co.in/books?id=-KSZAAAAIAAJ.

Anonymous, 2010. About pulp and paper production use. [Available at: www.panda.org/what_we_do/footprint/ Forestry/sustainable pulp paper/ about pulp paper production use].

Ashori, A., 2006. Non-wood fibres-A potential source of raw materials in papermaking. Polymer-Plastics Technology and Engineering 45(10), 1133-1136.

Bachheti, R.K., 2015. Chemical composition and antibacterial activity of the essential oil from the leaves of Eucalyptus globulus collected from Haramaya University, Ethiopia. Der Pharma Chemica 7(2), 209-214.

Bhagat, M., Gupta, S., Jamwal, V.S., Sharma, S., Kattal, M., Dawa, S., Devi, R., Bindu, K., 2016. Comparative study on chemical profiling and antimicrobial properties of essential oils from different parts of Eucalyptus lanceolatus. Indian Journal of Traditional Knowledge 15(3), 425-432.

Chanie, T., Collick, A.S., Adgo E., 2013. Eco-hydrological impacts of Eucalyptus in the semi humid Ethiopian Highlands: the Lake Tana Plain. Journal of Hydrology and Hydromechanics 61, 21-29.

Chaturvedi, A.N., Sharma, S.C., Srivastava, R., 1988. Water consumption and biomass production of some forest tree species. The International Tree Crops Journal 5, 71-76.

Chin, O., 2006. Rising preference for Eucalyptus poses dilemma in Eastern Africa, In: Eastern and Central African Policy Brief, 2006, ICRAF, 2.

Davidson, J., 1995. Ecological aspects of Eucalypts. In: Proceedings of Regional expert consultation on Eucalyptus. Vol. 1 FAO Regional Office for Asia and Pacific, Bangkok, Thailand.

Davidson, J., 1989. Ecological Aspects of Eucalyptus Plantations www.fao.org/3/ac777e/ac777e06.htm

Dereje, J., Mulugeta, L., Habtemariam, K., 2012. Expansion of eucalypt farm forestry and its determinants in Arsi Negelle District, south central Ethiopia. Small-scale Forestry 11(3), 389-405.

Dhakad, A.K., Panday, V.V., Beg, S., Rawat, J.M., Singh, A., 2017. Biological, medicinal and toxicological significance of Eucalyptus leaf essential oil: a review. Journal of the Science of Food and Agriculture 98(3), 833-848.

Dogra, A.S., 1984. Farm and agroforestry in south western
Punjab. In: Mathur, R.S. and Gogate, M.G. Eds. Agroforestry in India. Dehradun, FRI 157-177.

El-Baz, F.K., Mahmoud, K., El-Senousy, W.M., Darwesh, O.M., ElGohary, A.E., 2015. Antiviral, antimicrobial and schistosomicidal activities of Eucalyptus camaldulensis essential oils. International Journal of Pharmaceutical Sciences Review and Research 31(1), 262-268.

Gakuubi, M.M., 2016. Steam distillation extraction and chemical composition of essential oils of Toddalia asiatica L. and Eucalyptus camaldulensis Dehnh. Journal of Pharmacognosy and Phytochemistry 5(2), 99-104.

Ghosh, P.K., Kumar, S., Singh, G., 2014. Agronomic practices for agroforestry systems in India. Indian Journal of Agronomy 59(4), 497-510.

Indian Paper Manufacturers Association (IPMA), 2015. Eucalyptus Plantation: Socio-Economic and Environmental Impact, www.tnpl.com

Jagger, P., Pender, J., 2003. The role of trees for sustainable management of less-favored lands: the case of Eucalyptus in Ethiopia. Forest Policy and Economics 5, 83-95.

Jiregna, G., 2003. Water and nutrient relations of selected tree species of Ethiopia. PhD Dissertation, Stellenbosch University, Stellenbosch, South Africa, 180

Khan, S.A., 2003. Studies on sodic soils (Problematic Soils) rehabilitation through agroforestry system for central plain zone of Uttar Pradesh, India.

Lisanework, N., Michelsen, A., 1993. Allelopathy in Agroforestry systems the effects of leaf extracts of cupressus lusitanica and three eucalyptus spp. On four ethiopian crops. Agroforestry Systems 21, 63-74. http://dx.doi.org/10.1007/BF00704926

Liu, H., Li, J., 2010. The study of ecological problems of Eucalyptus plantation and sustainable development in moaming xiaoliang. Journal of Sustainable Development 3, 197-2001.

Luna, R.K., 1996. Plantation trees. International Book Distributors, Dehradun, Uttaranchal, 975.

Maiti, S.K., Rana, V., 2016. Assessment of heavy metals contamination in reclaimed mine soil and their accumulation and distribution in eucalyptus hybrid. Bulletin of Environmental Contamination and Toxicology 94(3), 269-274.

Mekonnen, Z., Kassa, H., Lemenh, M., Campbell, B.M., 2007. The role and management of Eucalyptus in Lode Hetosa district, central Ethiopia. Forest, Trees and Livelihood 17, 309-323.

Michelsen, A., Lisanework, N., Friis, I., 1993. Impacts of tree plantations in the Ethiopian highland on soil fertility shoot and root growth, nutrient utilization and mycorrhizal colonization. Forest Ecology and Management 61, 299-324.

Mishra, M., 2011. [Available at: http://www.ipma.co.in/paperindustryoverview.asp.].WWF (World Wildlife Fund). 
2010. About pulp and paper production use. [Available at: www.panda.org/what_we_do/footprint/Forestry/ sustainable pulp paper/about pulp paper production use].

Mishra, A., Sharma, S.D., Khan, G.H., 2003. Improvement in physical and chemical properties of sodic soil by 3, 6 and 9 years old plantation of Eucalyptus tereticornis Biorejuvenation of sodic soil. Forest Ecology and Management 184, 115-124.

Piare, L., 2006. Clonal forestry in India. In: Regional Consultation Workshop on Scope of Production Forestry for Carbon Sequestration, 7-8 December 2006. Proceedings. Dehradun, FSI.

Poore, M.E.D., Fries, C., 1987. The Ecological Effects of Eucalyptus. Natraj Publishers, Dehradun, 98.

Rani, N., Harikrishnan, T.J., Ponnudurai, G., 2016. In vitro insecticidal activity of essential oil of Eucalyptus globulus against Musca domestica. The Indian Veterinary Journal 93(9), 25-27.

Ram, J., Dagar, J.C., Khajanchi, L., Singh, G., Toky, O.P., Tanwar, V.S., Dar, S.R.,Chauhan, M.K., 2011. Bio drainage to combat waterlogging, increase farm productivity and sequester carbon in canal command areas of northwest India. Current Science 100(11), 1673-1680.

Rana, V., Joshi, G., Singh, S.P., Gupta, P.K., 2014. Eucalypts in India. Chapter; Eucalypts in pulp and paper industry. ENVIS RP on Forestry and Forest Related Livelihoods. http://frienvis.nic.in/

Rassaeifar, M., Hosseini, N., Haji H.A., Zandi, P., Moradi A.A., Rassaeifar, M., Hosseini, N., Hasani, N., Zandi, P., Aghdam, A., 2013. Allelopathic Effect Of Eucalyptus Globulus' Essential Oil On Seed Germination And Seedling Establishment Of Amaranthus Blitoides And CyndonDactylon. Trakia Journal of Sciences, 1, 73-81.
Samani, A.D., Ghahfarokhi, S.M., Samani, A.D., Kheirabadi, K.P., 2015. Acaricidal and repellent activities of essential oil of Eucalyptus globulus against Dermanyssus gallinae (Acari: Mesostigmata). Journal of HerbMed Pharmacology 4(3), 81-84.

Sharma, M., Sharma, C.L., Umar, Y.B., 2013. Evaluation of fibre characteristics in some weeds of Arunachal Pradesh, India for pulp and paper making. Research Journal of Agriculture and Forestry Sciences 1(3), 15-21.

Stape, J.L., Goncalves, J.L.M., Goncalves, A.N., 2001. Relationship between nursery practices and field performance for Eucalyptus plantations in Brazil. New Forests 22, 19-41.

SFIF (Swedish Forest Industries Federation), 2011. [Available at: http://www.forestindustries.se/documentation/ statistics_ppt_files/pulp_and_paper_industry_3/ paper_production_2].

Teketay, D., 2000. Facts and experience on Eucalyptus in Ethiopia and elsewhere: ground for making wise and informed decision. Workshop on Eucalyptus Dilemma, 15 November 2000.

Wessels, C.B., Nocetti, M., Brunetti, M., Crafford, P.L., Proller M., Dugmore, M.K., Pagel, C., Lenner, R., Naghizadeh, Z., 2020. Green-glued engineered products from fast growing Eucalyptus trees: a review. European Journal of Wood and Wood Products 78, 933-940.

Zegeye, H., 2010. Environmental and socio-economic implications of eucalyptus in Ethiopia. Ethiopian Institute Agricultural Research 2010, 184-205.

Zhou, L.J., Li, F.R., Huang, L.J., Yang, Z.R., Yuan, S., Bai, L.H., 2016. Antifungal activity of eucalyptus oil against rice blast fungi and the possible mechanism of gene expression pattern. Molecules 21, 1-11. 